\title{
Correlation of Balanced Socio-Economic Development of the City and Its Attractiveness (in the Case of Russian Cities with Population over a Million Citizens)
}

\author{
Glebova I.S.a \\ Khamidullina A.M. ${ }^{b}$ \\ Anisimova E.A.c \\ ${ }^{a b c}$ Kazan Federal University, Institute of Management, Economics and Finance, Kazan, 420008, Russia
}

Doi:10.5901/mjss.2015.v6n1s3p284

\begin{abstract}
This article evaluates balanced socio-economic development of the city and its influence on the territorial attractiveness. The hypothesis, that the cities which are developed in socio-economic balance are more attractive and more competitive, is taken as a base of the research. The article classifies the cities according to their level of balance and evaluates the rate of Russian cities with population over a million.
\end{abstract}

Keywords: city, balanced socio-economic development, attractiveness of the area, migration balance, investments attracted

\section{Introduction}

City is a complicated multilevel system, which includes a number of subsystems and elements which develop in interrelation and affect development of the city as a whole. Therefore the concept of the balanced development of the city is used more frequently. This concept includes proportional progressive development in several directions: demographic, ecologic, innovative etc. Balanced development of the city may also be viewed from the point of social and economic development. Social development of the city assumes creation of comfortable living conditions, enhancement of the social structure, maintenance of the wealth level at the high rate, and opportunities for the self-realization of the citizens.

The second key aspect of the city's development is the economical aspect. It includes the economical situation in the city as a whole, the purchasing power of the citizens, the presence of human resources, conditions for beginning and running a business, payback of the investments etc. The correlation of social and economic indexes predetermines the level of city's development balance which in its turn may affect the level of the territorial appeal. Therefore, the research of the balanced socio-economic development of the city and its affect on the territorial appeal is relevant.

There is no clear term for the concept of the balanced development in science. The concept of the balanced socioeconomic development of the territory will be described as the proportional simultaneous increase of the social and economic rates according to their correlation.

In the international practice the concept of the balanced development is often identified as the concept of sustainable development. The concept of sustainable development in conditions of competition between the cities for the finance, material and human resources becomes more relevant than ever. However, Lele S.M. [3] mentions that there is no common approach in definition of this concept. Some scientists consider sustainable development of the territories at different levels. Scientists Lanfranchi M. , Giannetto C. [2] and Pileček J. ,Chromý P, Jančák V. [8] consider sustainable development of the peripheral village territories as a concept that is directed to raise the attractiveness of these areas. Other scientists (L. Van Grunsven [1], B.A. Portnov, D. Pearlmutter [10] and other) focus on the sustainable development of the cities which take the leading part in the process of socio-economic development of territories and regions.

Due to the fact that there is no common approach in definition of sustainable development, there is also no common approach to the method of the evaluation of sustainability of development, and the definition of the factors which ensure the sustainable development.

As S. Moreno Pires, T. Fidelis and Ramos [7] mention in their article, various rates are used in evaluation of the sustainable development. At the same time these rates cannot be summarized what leads to the difficulty in the comparison of sustainable development of different territories. B.A. Revich, T.L. Kharkova, E.A.Kvasha, D.D. Bogoyavlensky, A.G. Korovkin, I.B. Korolev [11] emphasize socio-demographic rates as the key factors of the sustainable 
development. Mahon M. ,Fahy F., Cinnéide M.O. [5] take the quality of life as base factor.

It should be mentioned that frequently the researchers take the migration level (Pobiner J.A. [9],M. Lerch M [4] and others) the amount of attracted investments (Menghinello S., de Propris L., Driffield N. [6] and others) as the rates of sustainable socio-economic development. However, these rates are usually considered separately. The innovation of this research is in considering the migration level and the amount of attracted investments as a complex when evaluating the balanced socio-economic development of the city.

\section{Method}

The hypothesis, that the cities which are developed in socio-economic balance are more attractive and their competitive level is higher, is taken as a base of the research. This hypothesis may be explained by the fact that social and economic rates are interrelated. That is why the increase of some rates must lead to the balanced increase of the other rates. In other case, the fail in one of spheres (social or economic) will slow the development of the other sphere and by these means prevent the rise of level of the city's attractiveness. To test this hypothesis the research was done. The subject of the research was the following Russian cities with population over one million citizens: Volgograd, Yekaterinburg, Kazan, Nizhniy Novgorod, Novosibirsk, Omsk, Rostov-na-Donu, Samara, Ufa and Chelyabinsk. These cities were chosen due to their high level of development and attractiveness at the moment.

The research included several stages. Different methods were applied during each stage. On the first stage it was necessary to determine the level of social and economic development. To achieve the goal the method of correlation and the method of comparative analyses were used. The calculation of the correlation of social and economic development goes according to the formula:

$$
r=\frac{\overline{\mathrm{xy}}-\overline{\mathrm{x}} * \overline{\mathrm{y}}}{\sqrt{\left(\overline{\mathrm{x}^{2}}-(\overline{\mathrm{x}})^{2}\right) *\left(\overline{\mathrm{y}^{2}}-(\overline{\mathrm{y}})^{2}\right)}},
$$

where $\mathrm{r}$ - correlation coefficient, and $\mathrm{x}, \mathrm{y}$ - the rates which correlate with each other.

From the very beginning it was necessary to choose the key rates of the social and economic development. Thus, the following rates were chosen to evaluate the level of the social development of the cities with population over one million citizens: housing (per one citizen), subsistence wage, amount of children in kindergartens, amount of people who do sports, amount of crimes etc., At the same time the migration balance was chosen as the key rate. Initially there was an assumption that the territory with high level of social development will be comfortable to live in and the amount of those who came would increase and amount those who leave would decrease, so the balance of the migration would be positive. This assumption was tested on the base of correlative analyses of the migration balance and main rates of the social development. The result demonstrated that the migration balance has a strong interrelation with the rates of social development of the area and might be used as the base rate in evaluating the level of the social development of the area.

To evaluate the economic development the following rates were chosen: the average number of workers, number of loss-making companies, the cost of the minimum amount of food necessary for living etc. The amount of attracted private investments was chosen as the key rate as it reflects the attractiveness of running a business on the territory of the city. The same way the correlative analysis was performed with key rates of the economic development of the territory. It was confirmed, that amount of attracted investments may reveal the level of economic development of the territory as it is strongly interrelated with other economic rates.

Therefore it was proved that migration balance and amount of attracted investments may be the basic rates in evaluation of social and economic development.T

After defining the key rates of social and economic development the comparative analyses of the cities with population over one million citizens according to the level of balance of socio-economic development was done. To illustrate there was created a matrix with two axis: migration balance and amount of attracted investments. Initially there was calculated the average level of each rate and there were marked sections named "above average level" and "below average level" on both axis. Therefore the following four cells of matrix were selected:

1) if migration balance and amount of attracted investments are below the average level, the cities have balanced, but relatively low level of development;

2) if migration balance is above the average level and amount of attracted investments is below the average level, the cities have misbalanced, but relatively high level of social development;

3) if migration balance is below the average level and amount of attracted investments is above the average level, the cities have misbalanced, but relatively high level of economic development;

4) if migration balance and amount of attracted investments are above the average level, the cities have balanced, relatively high level of development; 
The average rates of balance of migration and attracted investments during the five-year-period (from year 2008 to 2012) were calculated to put each city with population over one million citizens into the appropriate position in the matrix. The average rate was calculated to evaluate reasonably the level of development of the cities excluding yearly moves due to other factors (for example economic crisis).

After defining the level of socio-economic balance of the cities, the evaluation of the cities' attractiveness was performed. Comparative analyses using ranking method was taken as a base in evaluating attractiveness of the cities. Social development rates were used along with economic rates in this ranking. The rate of the city $(R)$ was calculated according to the formula:

$\mathrm{R}=\sum_{1}^{n}\left(\mathrm{R}_{\mathrm{n}} * \mathrm{r}_{\mathrm{i}} * \mathrm{r}_{\mathrm{m}}\right)$,

where $R_{n}$ - the rate of the city's attractiveness according to socio-economic development level, $r_{i}-$ coefficient of correlation of the investments attracted to the economy of the city, and $\mathrm{r}_{\mathrm{m}}$ - coefficient of correlation of the migration balance.

Further analyses of the data received, confirmed the hypothesis proposed in the beginning of the research.

\section{Result}

During the determination of the social and economic balance level of each city with population over a million citizens, the average rates of migration balance and attracted investments were calculated. The cities were set up in the matrix of socio-economic balance according to these rates (Pic.1)

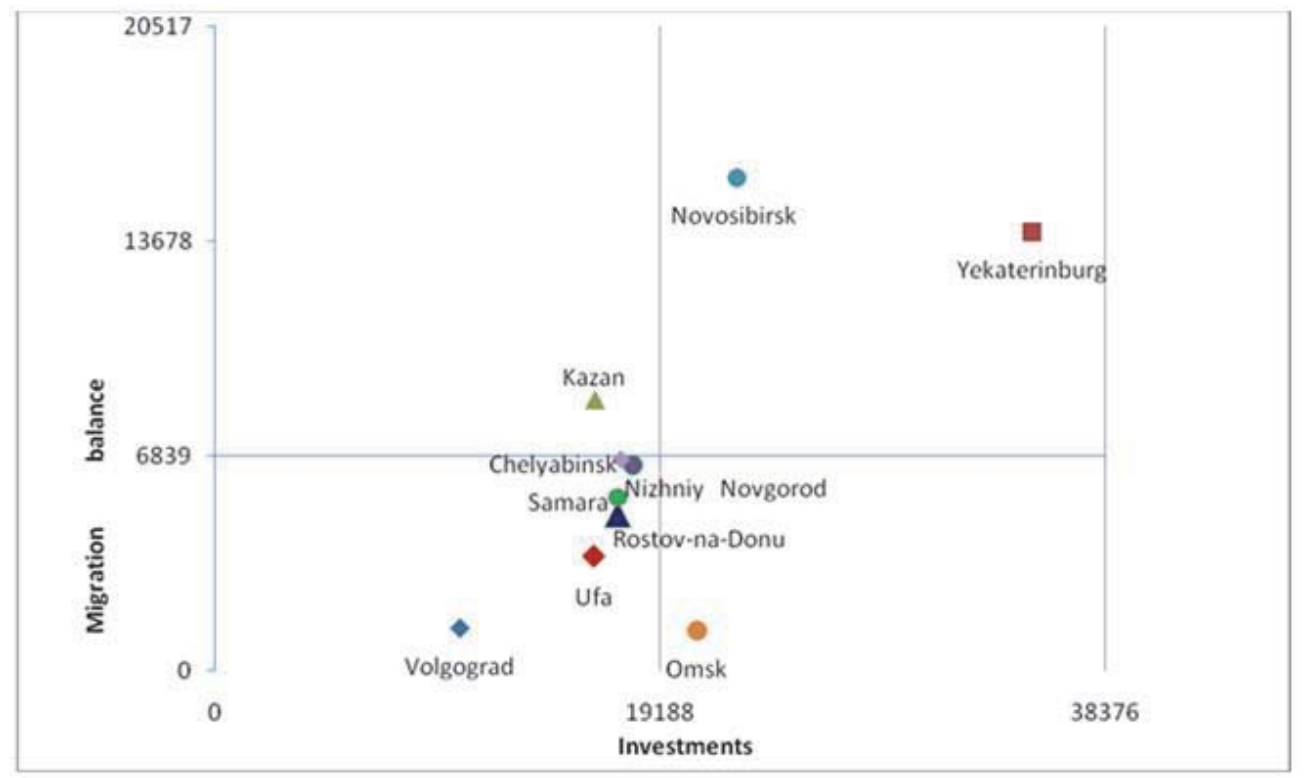

Pic 1. The matrix of socio-economic balance of the cities.

As a result the cities in the matrix are set up as follows:

1) Volgograd, Nizhniy Novgorod, Rostov-na-Donu, Samara, Ufa, Chelyabinsk are thecities which with balanced, but relatively low level of development;

2) Kazan is the city with misbalanced but relatively high level of social development

3) Omsk is the city with misbalanced but relatively high level of economic development.

4) Yekaterinburg, Novosibirsk are the cities with balanced high level of development;

Furthermore the level of attractiveness of the cities with population over a million citizens was determined according to the calculation of the rates. It allowed setting up each city in its place in the chart of cities' attractiveness (the top score is 1) (tab. 2) 
Table 1. The chart of attractiveness of the cities.

\begin{tabular}{|c|l|c|}
\hline Rate & City & Coefficient \\
\hline 10 & Volgograd & 8,6629 \\
\hline 1 & Yekaterinburg & 30,1054 \\
\hline 3 & Kazan & 23,0693 \\
\hline 5 & Nizhniy Novgorod & 21,2094 \\
\hline 2 & Novosibirsk & 23,9646 \\
\hline 9 & Omsk & 16,7604 \\
\hline 6 & Rostov-na-Donu & 18,4735 \\
\hline 7 & Samara & 17,8456 \\
\hline 8 & Ufa & 17,5831 \\
\hline 4 & Chelyabinsk & 22,0528 \\
\hline
\end{tabular}

This research determined the level of balance and attractiveness of the Russian cities with population over one million citizens.

\section{Conclusion}

According to the research done, there was made a conclusion that the initial hypothesis that balanced socio-economic development predetermines the higher level of the city's attractiveness.

The cities with population over one million citizens which according to the classification are in the group of cities that possess balanced and relatively high level of development (group 4) take leading places in the attractiveness chart. Yekaterinburg is on the 1-st place, Novosibirsk is on the 2-nd place. The strategy of these leading cities is to preserve the level of social and economic balance.

Kazan is on the 3-rd place. It relates to the 2-nd group of cities, the group of cities that possess misbalanced but relatively high level of social development. The social aspect ensures relatively high level of attractiveness of the city. However it should be mentioned that Kazan still gives in attractiveness to the cities with balanced and relatively high level of development. This proves the thesis that the cities that develop proportionally in both social and economic aspects are more attractive.

The next in the chart of attractiveness are the cities that possess balanced but relatively low level of development (group 1.) Such exposition of the cities in the chart disproves the correctness of the hypothesis. According to the hypothesis these cities must have been higher in the chart than those of groups 2 and 3.

However the research revealed reverse result. On the basis of this it may be concluded that the initial hypothesis is correct only in definite conditions. In case if the level of development of the city is above average, the main priority will be balanced development in both social and economic directions. If the level of development is below average the vital for the city will be the strategy of creating the points of growth which will help to withstand competition and raise the level of self-attractiveness. It will set the base for the future balanced socio-economic development.

Thus, during the research it was found that the balanced development of the city actually affects its attractiveness. At the same time it is necessary to choose the development strategy according to the level of socio-economic development: whether to raise the level of development balance, or to create the points of growth to raise the level of the city's attractiveness and competiveness.

\section{References}

Van Grunsven L. The sustainability of urban development in the SIJORI Growth Triangle: A social perspective//International Development Planning Review (20), 1998.pp. 179-201.

Lanfranchi M.,Giannetto C. Sustainable development in rural areas: The new model of social farming // Quality - Access to Success(15), 2014.pp. 219-223.

Lélé, S.M. Sustainable development: A critical review // World Development (19), 1991.pp. 607-621.

Lerch M. The Role of Migration in the Urban Transition: A Demonstration From Albania // Demography(51), 2014. pp.527-1550.

Mahon M., Fahy F., Cinnéide M.O. The significance of quality of life and sustainability at the urban-rural fringe in the making of placebased community // GeoJournal(77), 2012. pp.265-278.

Menghinello S., de Propris L., Driffield N. Industrial districts, inward foreign investment and regional development // Journal of Economic Geography(10), 2010.pp. 539-558.

Safiullina, A.M., Odintsova, J.L., Zhilina, N.N.,Shamsutdinova, M.R. The main participants of innovation climate development (on the 
example of the Russian federation). Mediterranean Journal of Social Sciences, 5 (18 SPEC. ISSUE), pp. 197-202.

Razumovskaya, E.M. , Kutsevol, N., Popov, M., Mishakin, T., Leto, L., Tsalikova, V. The effectiveness of management practice in the market of socially important services, Asian Social Science, Volume 10, 28 September 2014, Pages 118-122.

Moreno Pires S., Fidélis T., Ramos, T.B. Measuring and comparing local sustainable development through common indicators: Constraints and achievements in practice // Cities (39), 2014.pp. 1-9.

Razumovskaya, E.M., Mishakin, T.S., Popov, M.L., Kucevol, N.G. Medical services during the XXVII world summer universiade 2013 in Kazan. Mediterranean Journal of Social Sciences, Volume 5, Issue 18 SPEC. ISSUE, 2014, Pages 17-20.

Bagautdinova, N.G., Fatkhiev, A.M., Novenkova, A.Z., Safiullina, A.M. (2014). The stages of the innovation process. Recent Trends in Social and Behaviour Sciences - Proceedings of the 2nd International Congress on Interdisciplinary Behavior and Social Sciences 2013, ICIBSoS 2013, Pages 315-318.

Pileček J., Chromý P, Jančák V. Social Capital and Local Socio-economic Development: The Case of Czech Peripheries // TijdschriftvoorEconomische en SocialeGeografie(104), 2013.pp. 604-620.

Pobiner J.A. The impact of population increase and urban migration on global sustainability and quality of life // WIT Transactions on Ecology and the Environment(179), 2014.pp. 235-245.

Portnov B.A., Pearlmutter D. Sustainable urban growth in peripheral areas //Progress in Planning (52), 1999.pp. 239-308.

Revich B.A., Kharkova T.L., Kvasha E.A., Bogoyavlenskii D.D., Korovkin A.G., Korolev I.B. Sociodemographic limitations of the sustainable development of Murmansk oblast // Studies on Russian Economic Development(25), 2014.pp. 201-206. 